\title{
Propolis: recent advances in chemistry and plant origin
}

\author{
Vassya S. BANKOVA ${ }^{\mathrm{a} *}$, Solange L. DE CASTRO ${ }^{\mathrm{b}}$, \\ Maria C. MARCUCCI \\ ${ }^{a}$ Institute of Organic Chemistry with Centre of Phytochemistry, \\ Bulgarian Academy of Sciences, 1113 Sofia, Bulgaria \\ b Laboratorio de Biologia celular, DUBC, Institute Oswaldo Cruz, \\ Cx. Postal 926, 21045-900 Rio de Janeiro, RJ, Brazil \\ ${ }^{\mathrm{c}}$ Faculdade de Farmacia, Bandeirante University of Sao Paulo, \\ Avenida Rudge Ramos, 1501, Campus ABC, 09736-310 Sao Paulo, SP, Brazil
}

(Received 27 January 1999; accepted 27 September 1999)

\begin{abstract}
New information published since 1995 about propolis constituents is reviewed. The available information on the biological action of new found components is presented. Recent publications are reviewed on propolis of native South American stingless bees. The plant sources of bee glue are discussed, taking into consideration data based on reliable chemical evidence including comparisons between propolis samples and plant material. Some aspects of the chemical standardization of propolis are discussed.
\end{abstract}

propolis / plant origin / stingless bees / phenolics / terpenes / Apis mellifera

\section{INTRODUCTION}

Propolis (bee glue) is a sticky darkcoloured material that honeybees collect from living plants, mix with wax and use in construction and adaptation of their nests. The term 'propolis' was used by authors in Ancient Greece: pro (for, in front of, e.g., at the entrance to) and polis (city or community); a substance that is for or in defence of the city or hive $[19,23]$. Bees apply propolis in a thin layer on the internal walls of their hive or other cavity they inhabit. It is used to block holes and cracks, to repair combs, to strengthen the thin borders of the comb, and for making the entrance of the hive weathertight or easier to defend. Propolis also is used as an "embalming" substance to cover hive invaders which bees have killed but cannot transport out of the hive

\footnotetext{
* Correspondence and reprints

E-mail: bankova@orgchm.bas.bg
} 
[23]. Bees make use of the mechanical properties of propolis and of its biological action: bee glue contains the putrefaction of the "embalmed" intruders, it is responsible for the lower incidence of bacteria and moulds within the hive than in the atmosphere outside [23]. The action against micro-organisms is an essential characteristic of propolis and it has been used by human beings since ancient times for its pharmaceutical properties. Propolis possesses antibacterial, antifungal and antiviral properties and many other beneficial biological activities: antiinflammatory, antiulcer, local anaesthetic, hepatoprotective, antitumor, immunostimulating, etc. $[15,23,31]$. For this reason propolis is widely used as a popular remedy in folk medicine, in apitherapy [42], as a constituent of "biocosmetics", "health food" and for numerous further purposes $[35,52]$.

These properties of propolis have attracted the attention of scientists since the late 60's. During the last 40 years, many investigations have been published on the chemical composition, biological activity, pharmacology and therapeutical uses of propolis. The first comprehensive review was published by Ghisalberti in 1978 [23]. According to the author it was an attempt "to collect most of the information about propolis which has been published over the last 70 years" (i.e., since the beginning of the 20th century). In this excellent article, a statement was made that "because its composition is largely unknown, propolis should not be recommended in medicines", and "it will have to be studied much more before it can properly be considered for therapeutical purposes". Twenty years later, there is a considerable information on the chemistry and biological activity of propolis but the situation with its application in therapy has barely changed. The main problem is the striking variability of its chemical composition depending on the site of collection, because in different ecosystems different plant exudates and secretions could serve as a source of propolis. This is a great prob- lem especially for samples originating from tropical regions. The chemical standardization of propolis based on its "active principles" has not been realized. It is one of the aims of this review, to clarify the question whether such a standardization is possible and what could it look like, based on the actual knowledge.

The chemical composition of propolis has been the subject of some reviews [23, $31,50,51]$. The present paper covers the information on new propolis constituents, published after 1994 and not included in the latest review article of Marcucci from 1995 [31]. A comprehensive review on the biological activity of bee glue has recently been published by [15].

\section{PLANT SOURCES}

\subsection{How are plant sources identified?}

The most important materials collected by honeybees, nectar and pollen, are referred to by their botanical names. On the other hand, "propolis" is a bee-oriented term that does not have a botanical derivation. The materials available to bees for "manufacturing" of propolis are produced by a variety of botanical processes in different parts of plants. These are, according to Crane [19], substances actively secreted by plants and substances exuded from wounds in plants: lipophylic materials on leaves and leaf buds, mucilages, gums, resins, latices, etc. In her monograph [19], Crane gives a long list of plants thought to be sources of propolis in different parts of the world. It is important to note that this list is based principally on observations of bee behaviour and only in a few cases on comparative chemical analysis of propolis and plant materials. This list must be regarded only as a preliminary information because propolis collection is a relatively rare activity of honeybees and often it takes place high up in the trees, so it is difficult to be observed [19]. For this reason we discuss only data based on reliable 
chemical evidence that includes comparison between propolis samples and plant material.

\subsection{Propolis sources in the temperate zone}

The first papers to analyze propolis based on chemical evidence appeared in the 70's: Lavie [29] in France and Popravko [44] in Russia analyzed propolis flavonoid composition and compared it to poplar and birch bud exudates, respectively. Many other publications followed and now it is generally accepted and chemically demonstrated that in temperate zones the bud exudates of Populus species and their hybrids are the main source of bee glue. This is true for Europe [2, 24, 40, 44, 45], North America [21], and the non-tropical regions of Asia [3, 16]. Even in New Zealand, introduced poplar species are the source plants [33]. In Russia however, and especially in its northern parts, birch buds (Betula verrucosa) supply bees with the worthy glue [44].

\subsection{Plant sources of tropical propolis}

In tropical regions there are no poplars and birches, and bees have to find new plant sources of bee glue. Identifying the main propolis flavonoids in samples from "border areas" with almost tropical climate, where poplars are not always available, Martos et al. [34] found the leaf exudate of some Cistus spp. to be a plant source of propolis in Tunisia. Analogously, in the Sonoran Desert Ambrosia deltoidea was the plant source [52]. From propolis samples from tropical Venezuela, Tomas-Barberan et al. [48] isolated polyprenylated benzophenones. These compounds are main components of the resin exuded by the flowers of some $\mathrm{Clu}$ sia species and, based on chromatographic comparison, the authors demonstrated that Clusia major and Clusia minor (Guttiferae) were the main sources of propolis in the region concerned.
There are chemical studies on propolis plant sources in Australia (Xanthorrhoea spp. - [22]) and Brazil (Araucaria spp. [5], Baccharis spp. - [9, 32]) but in these cases there was no direct comparison between propolis and plant material and they must be regarded only as guidelines for future work.

\subsection{Importance of the knowledge of plant sources}

The knowledge about plant sources of propolis is not only of academic interest. It could be useful as a basis for the chemical standardization of propolis. Bee glue could be easily characterized using its plant source, which might be established by simple TLC [43], HPLC or GC comparison. As far as the composition of the corresponding plant exudates is known, this method gives information about the qualitative composition of the sample. For example, speaking about "poplar type" propolis, it is clear that the product is a mixture of flavonoid aglycones, hydroxycinnamic acids and their esters.

In addition, knowledge of propolis plant sources is important to beekeepers to be sure that their bees have the proper plants in their flight range. It is known that colonies suffer when they cannot collect propolis, bees are even said to use "propolis substituents" like paints, asphalt and mineral oils which could severely threaten pharmaceutical uses of bee glue [27].

\section{CHEMICAL COMPOSITION}

\subsection{New compounds in temperate zone propolis}

As already mentioned, the chemical composition of bee glue is very complex and depends on the flora in the areas where it is collected. In the temperate zone, including Europe, Asia and North America, bud exudates of different poplar buds are the main 
source of propolis. Samples originating from these regions are characterized by similar chemical composition, the main constituents being phenolics: flavonoid aglycones, aromatic acids and their esters [31]. Hereunder bold figures refer to the new propolis constituents. Markham et al. [33] identified in samples from New Zealand the usual "poplar" phenolics (originating from introduced poplars), together with two new compounds: 5-phenyl-trans, trans-2,4-pentadienoic acid 1 and 5-phenyl-trans-3pentenoic acid 2. In a propolis sample from Egypt, along with poplar bud constituents, esters of caffeic acid with long-chain fatty alcohols (dodecanol, tetradecanol, tetradecenol, hexadecanol) were identified [17] (3-6).

\subsection{New compounds in tropical propolis}

In the last few years propolis from tropic regions and especially from Brazil has become the subject of increasing interest. This has led to the identification of many new compounds in propolis, some of them possessing remarkable biological activity.

\subsubsection{Flavonoids}

Investigations on tropical bee glue revealed that in many cases flavonoids are important components of these samples, which is analogous to European samples, although their plant origin is different. In samples from the Sonoran Desert, Wollenweber \& Buchmann [52] identified flavonoid aglycones typical for leaf exudates of Ambrosia deltoidea; among them 5,7,4'-trihydroxy-6,8-dimethoxyflavone 9 and sideritiflavone 10 being new for propolis. Myricetin $3,7,4^{\prime}, 5^{\prime}$ '-tetramethyl $\mathbf{1 1}$ ether and quercetin 3,7,3'-trimethyl ether $\mathbf{1 2}$ were isolated from Tunisian propolis, which originated from leaf exudates of Cistus species [34]. In Brazilian samples, kaempferid, 5,6,7-trihydroxy-3,4'-dihydroxyflavon $\mathbf{1 3}$, aromadendrine-4'methyl ether 14 [14] and 3,5,7-trihydroxy-6,4'-dimethoxyflavon $\mathbf{1 5}$ [9] were identified.

\subsubsection{Prenylated p-coumaric acids and acetophenones}

Another class of phenolics newly found in Brazilian bee-glue, are prenylated p-coumaric acids and their derivatives with cyclized prenyl residues: 16-22 [1, 9, 14, $39,47]$.

Acetophenone derivatives containing a modified prenyl-substituent (23-25) also have been isolated from Brazilian propolis [9]. Prenylated p-coumaric acids and acetophenones are secondary metabolites, typical for South American Baccharis species [12].

\subsubsection{Lignans and other phenolics}

Recent investigations of tropical propolis from countries other than Brazil resulted in the identification of a series of lignans, whose plant sources still remain unknown. In propolis from the Canary Islands, thirteen lignans of the furofuran type were found by GC-MS, most of them were only tentatively identified [7]. Four of them were isolated and characterized as sesamin 37, aschantin 38, sesartenin 39 and yangambin 40 [18]. Valcic et al. [49] isolated four new lignans from Chilean bee glue: one trimer 34, two diastereomeric dimers $\mathbf{3 5}$ and the dihydrobebzofuran $\mathbf{3 6}$ (the latter was found also in Brazilian samples [6, 9]).

Other phenolic substances were isolated from Brazilian propolis, too: caffeoylquinic acid derivatives (26-33) [10, 46]; C-guayacylglycerol 8 [47], and the free radical scavenger 3-[4-hydroxy-3-(3-oxobut-1-enyl)phenyl]acrylic acid 7 [11].

\subsubsection{Di- and triterpenes}

Diterpenes seem to be another important class of Brazilian propolis constituents. New diterpenic acids with valuable biological 
activities have been identified: an antitumor clerodane derivative 41 [38], the cytotoxic substances 42 and its E-isomer [39] and antibacterial labdane type acids: 43-46 [5]. Banskota et al. isolated and identified four further labdane derivatives, 47-50 [9].

Some triterpenic alcohols were present in bee glue from Brazil and Egypt: $\beta$-amyrin $\mathbf{5 1}$, triterpenic alcohols of amyrin type and cycloartenol $\mathbf{5 2}[17,32]$.

\subsection{Volatile compounds}

Volatile compounds are found in low concentrations in propolis, but their aroma and significant biological activity $[26,30]$ make them of importance for the characterisation of propolis. In propolis volatiles, a number of new propolis components were identified, mainly mono- and sesquiterpenoids (Tab. I) $[4,7,13]$. The volatiles from

Table I. New components identified in propolis.

\begin{tabular}{|c|c|c|}
\hline No & Compound & References \\
\hline \multicolumn{3}{|c|}{ Aromatic compounds } \\
\hline 1. & 5-phenyl-trans, trans-2,4-pentadienoic acid & [33] \\
\hline 2. & 5-phenyl-trans-3-pentenoic acid & [33] \\
\hline 3. & dodecyl caffeate & {$[17]$} \\
\hline 4. & tetradecenyl caffeate & [17] \\
\hline 5. & tetradecyl caffeate & {$[17]$} \\
\hline 6. & hexadecy caffeate & [17] \\
\hline 7. & (+)-treo-1-C-quayacylglycerol & {$[47]$} \\
\hline 8. & 3-[4-hydroxy-3-(3-oxobut-1-enyl)-phenyl]acrylic acid & [11] \\
\hline \multicolumn{3}{|c|}{ Flavonoids } \\
\hline 9. & $5,7,4$ '-trihydroxy-6,8-dimethoxy flavone & [53] \\
\hline 10. & sideritiflavone & [53] \\
\hline 11. & myricetin $3,7,4^{\prime}, 5^{\prime}$-tetramethyl ether & [34] \\
\hline 12. & quercetin $3,7,3$ '-trimethyl ether & [34] \\
\hline 13. & 5,6,7-trihydroxy-3,4'-dihymethoxyflavon & {$[14]$} \\
\hline 14. & aromadendrine-4'methyl ether & {$[9,14]$} \\
\hline 15. & 3,5,7-trihydroxy-6,4'-dimethoxyflavon & [9] \\
\hline \multicolumn{3}{|c|}{ Prenylated $p$-coumaric acids } \\
\hline 16. & 3,5-diprenyl-4-hydroxycinnamic acid & {$[1,14,36]$} \\
\hline 17. & 3-prenyl-4-dihydro-cinnamoyloxycinnamic acid & {$[1,9]$} \\
\hline 18. & 2,2,-dimethyl-6-carboxyethenyl-2H-1-benzopyran & {$[1,9]$} \\
\hline 19. & 9-E-,2-dimethyl-6-carboxyethenyl-8-prenyl-2H-1-benzopyran & {$[9,14,36]$} \\
\hline 20. & 3-prenyl-4-hydroxycinnamic acid & [9] \\
\hline & 3-prenyl-4-(2-methoxypropionyl)-cinnamic acid & [47] \\
\hline & (E)-3-[2,3-dihydro-2-(1-hydroxy-1-methylethyl)-prenyl- & \\
\hline & benzofuran-5-yl]-2-propenoic acid & [47] \\
\hline \multicolumn{3}{|c|}{ Acetophenone derivatives } \\
\hline 23. & 2-[1-methyl]-vinyl-5-acetylcumarane & [9] \\
\hline 24. & 2-[1-hydroxymethyl]-vinyl-6-acetyl-5-hydroxycumarane & [9] \\
\hline 25. & 2-[1-acetoxymethyl]-vinyl-6-acetyl-5-hydroxycumarane & [9] \\
\hline \multicolumn{3}{|c|}{ Caffeoylquinic acids } \\
\hline 26. & 3-caffeoylquinic (chlorogenic) acid & {$[46,47]$} \\
\hline 27. & 4-caffeoylquinic acid & {$[46,47]$} \\
\hline
\end{tabular}


Table I. (Continued).

\begin{tabular}{|c|c|c|}
\hline No & Compound & References \\
\hline 28. & 5-caffeoylquinic acid & {$[46,47]$} \\
\hline 29. & 3,5-dicaffeoylquinic acid & {$[46,47]$} \\
\hline 30 . & 4,5-dicaffeoylquinic acid & {$[46,47]$} \\
\hline 31. & 4,5-dicaffeoylquinic acid methyl ester & [10] \\
\hline 32. & 3,4-dicaffeoylquinic acid & {$[46,47]$} \\
\hline 33. & 3,4-dicaffeoylquinic acid methyl ester & {$[10]$} \\
\hline \multicolumn{3}{|c|}{ Lignans } \\
\hline 34. & $\begin{array}{l}\text { 1-(4-hydroxy-3-methoxyphenyl)1,2-bis }\{4-[(\mathrm{E})-3- \\
\text { acetoxypropen-1-yl]-2-methoxyphenoxy }\} \text {-propan-3-ol acetate }\end{array}$ & [49] \\
\hline \multirow[t]{2}{*}{35.} & 1-(4-hydroxy-3-methoxyphenyl)-2-\{4-[(E)-3-acetoxypropen-1 & \\
\hline & -yl]-2-methoxyphenoxy\}propan-1,3-diol 3-acetate (erythro- and treo) & [49] \\
\hline 36. & $\begin{array}{l}\text { 3-acetoxymethyl-5-[(E)-2-formylethen-1-yl]-2-(4-hydroxy-3- } \\
\text { methoxyphenyl)-7-methoxy-2,3-dihydrobenzofuran }\end{array}$ & {$[6,9,49]$} \\
\hline 37. & sesamin & {$[18]$} \\
\hline 38. & aschantin & [18] \\
\hline 39. & sesartenin & [18] \\
\hline 40. & yangambin & [18] \\
\hline
\end{tabular}

Diterpenic acids

41. ent-17-hydroxy-3,13Z-clerodadien-15-oic acid

42. 15-oxo-3,13Z-kolavadiene-17-oic acid and its E-isomer

43. communic acid [5]

44. imbricatoloic acid

45. isocupressic acid

46. acetylisocupressic acid

47. 8(17),13E -labdadien-15,19-dioic acid

48. 8(17),13E -labdadien-15,19-dioic acid 15-methyl ester

49. 19-oxo-8(17),13E-labdadien-15-oic acid [9]

50. 13-hydroxy-8(17),14-labdadien-19-oic acid [9]

Triterpenes

51. $\beta$-amyrin $[17,32]$

52. cycloartenol $\quad[17,32]$

Components of volatiles (by GC-MS)

Monoterpenes

$\begin{array}{lll}\mathbf{5 3} & \alpha \text {-pinene } & {[13]} \\ \mathbf{5 4} & \beta \text {-pinene } & {[13]} \\ \mathbf{5 5} & \gamma \text {-terpinene } & {[13]} \\ \mathbf{5 6} & \text { geraniol } & {[7]} \\ \mathbf{5 7} & \text { linalyl propionate } & {[7]}\end{array}$

Sesquiterpenes

59. spatulenol

[4]

60. isospatulenol

61. palustrol

62. ledene

63. germacren $\mathrm{d}$ 
Table I. (Continued).

\begin{tabular}{clc}
\hline No & Compound & References \\
\hline Aromatic & compounds & \\
$\mathbf{6 4}$. & prenylacetophenone & {$[4]$} \\
$\mathbf{6 5}$. & diprenylacetophenone & {$[4]$} \\
$\mathbf{6 6}$. & 3-phenylpropanol & {$[4]$} \\
$\mathbf{6 7}$. & $\alpha$-methyl benzylalkohol & {$[4]$} \\
$\mathbf{6 8}$. & piperonal & {$[7]$} \\
& & \\
Sugars and sugar alkohols & \\
$\mathbf{6 9} . \quad$ xylose & {$[7]$} \\
$\mathbf{7 0} . \quad$ galactose & {$[7]$} \\
$\mathbf{7 1}$. & mannose & {$[7]$} \\
$\mathbf{7 2}$. & glucuronic acid & {$[7]$} \\
$\mathbf{7 3}$. & lactose & {$[7]$} \\
$\mathbf{7 4}$. & maltose & {$[7]$} \\
$\mathbf{7 5}$. & melibiose & {$[7]$} \\
$\mathbf{7 6}$. & erytritol & {$[7]$} \\
$\mathbf{7 7}$. & xylitol & {$[7]$} \\
$\mathbf{7 8}$. & inositol & {$[7]$} \\
\hline
\end{tabular}

tropical regions contained some sesquiterpenoids that were not found in samples from the temperate zone, e.g. ledol 58, spatulenol 59, germacren d 63. Prenylated acetophenones were found in volatiles from Brazilian samples, together with other aromatic compounds new for propolis (Tab. I).

\subsection{Sugars}

In samples from the Canary Islands [7], a significant number of different sugars and sugar alcohols were found, some of the compounds being new for propolis (Tab. I), including disaccharides. The compounds were identified by GC-MS. Their high percentage is an indication that they originate from some mucilage, which should be one of the sources of propolis specific to the Canary Islands.

\subsection{Hydrocarbons}

Propolis waxes from Brazilian samples were recently analyzed. The hydrocarbons and monoesters found were similar to those of European samples. According to this work, the composition of propolis wax is similar to that of comb wax, which suggests that propolis waxes are secreted by bees, rather than originating from plants [41].

\subsection{Mineral elements}

In recent studies on the mineral elements of propolis, $\mathrm{Ca}, \mathrm{Mg}, \mathrm{K}, \mathrm{Na}, \mathrm{Fe}$ and $\mathrm{Zn}$ were determined in Macedonian samples [28], and $\mathrm{Fe}, \mathrm{Mn}, \mathrm{Zn}$ and $\mathrm{Cu}$ in ethanolic extracts of Cuban samples [20]. Both studies were carried out using atomic absorption spectroscopy.

\subsection{Biological activity of the new components}

It is important to note that most of the latest investigations on new propolis constituents are connected to their biological activity. This information is summarized in Tab. II. Some of the prenylated p-coumaric acids possess antibacterial [1] and cytotoxic activities [36]. Caffeoylquinic acid 
Table II. Biological activity of new propolis constituents.

\begin{tabular}{lll}
\hline Type of activity & Compound & References \\
\hline Antibacterial & $\mathbf{1 6}-\mathbf{1 8}, \mathbf{4 2}-\mathbf{4 5}, \mathbf{3 6}-\mathbf{3 9}$ & {$[1,5,18]$} \\
Cytotoxic & $\mathbf{1 4}-\mathbf{1 6}, \mathbf{1 9}, \mathbf{3 5}, \mathbf{4 0}, \mathbf{4 1}$ & {$[9,36-39]$} \\
Imunomodulating & $\mathbf{2 6}-\mathbf{2 9}, \mathbf{3 1}$ & {$[46]$} \\
Antihepatotoxic & $\mathbf{3 0}, \mathbf{3 2}$ & {$[10]$} \\
\hline
\end{tabular}

derivatives (26-33) showed immunomodulatory and hepatoprotective action $[10,46]$. The furofuran lignans 37-40 were shown to inhibit the growth of some bacteria [18]. Diterpenic acids isolated from Brazilian propolis showed cytotoxic (42 and its E-isomer [39]) and antibacterial (43-46, [5]) activity.

This is a fruitful trend that could give important hints about the possibilities for standardization. However, the only conclusion that can be drawn at this point is, that systematic investigations are needed to determine the chemical composition, biologically active compounds and basic plant sources of propolis in different geographic regions. This knowledge might help to formulate a limited number of "chemical types" of propolis and the biological activities related to this chemistry.

\subsection{Chemical composition of geopropolis}

Until now, the investigations on tropical propolis concentrated almost exclusively on Apis mellifera bee glue. In tropical South America there are indigenous stingless bee species (Meliponinae), which collect resinous material from plants and mix it with beeswax and soil to form geopropolis [25]. Only two investigations have been published on this type of propolis although it has become the subject of an increasing interest. Tomas-Barberan et al. [48] investigated the phenolic constituents of propolis and geopropolis by HPLC from Venezuela and found that prenylated benzophenones predominated in all the samples. Five indigenous bee species were investigated together with honey bee, and there were no differences in the chemical composition of their propolis. In a recent publication, Bankova et al. [8] studied the chemical composition of geopropolis from three Brazilian stingless bee species by GC-MS and found that the composition varied with the location and bee species, and was different from the geopropolis in Venezuela. The main components of these samples were diterpenic acids and triterpenes (alcohols and ketones). Determining the components of geopropolis is an interesting field for future research activities, especially with respect to the information that it possesses biological activity similar to that of honey bee propolis [25].

\section{CONCLUSIONS AND PERSPECTIVES}

Propolis is a natural product with a great potential for use in human and veterinary medicine. On the other hand, unlike products derived from medicinal plants, its composition is extraordinary variable; samples from different geographic origin may possess totally different chemical compositions. This variability creates a weighty problem for the medical use of propolis and its quality control. The main difficulties encountered are related to the absence of any control on the origin of propolis, and knowledge of the origin is crucial in determining the composition. Further research is needed on the chemical composition of bee glue and on biological activities of substances 
isolated from it. In particular, the discovery of propolis plant sources in different geographic regions could be of great importance. Knowledge of the active compounds could lead to the formulation of a number of "local" propolis types based on plant origin; e.g. "European", "North Russian", some kinds of "Brazilian". Table III gives the most typical constituents of propolis samples from different geographic locations and their plant sources. For the purposes of quality control, chemical tests have to be combined with biological ones, especially antimicrobial tests. Characteristics of the purity, like percentage of beeswax, insoluble residue, etc., must be involved, as well. This approach requires systematic investigations of the chemistry and biological action of bee glue in large regions and is only possible with the joint efforts of many scientists, beekeepers, public national and international organisations, and governments. It is our hope that this article will attract some attention to the problems described stimulate further research on propolis, a valuable gift of Nature.

\section{ACKNOWLEDGEMENTS}

Partial support of this work by the National Foundation for Scientific Research of Bulgaria (Contract \# X-715), FAPESP (Fundacao de
Amparo a pesquisa do Estado de São Paulo) and Conselho Nacional de Desenvolvimento Cientifico e Tecnologico e Fundacao Oswaldo Cruz is gratefully acknowledged.

Résumé - Récents progrès dans la chimie de la propolis et son origine végétale. La propolis est un matériau multifonctionnel utilisé par les abeilles pour la construction et la maintenance de leurs ruches. Elle est utilisée par l'Homme depuis longtemps. En raison de ses activités biologiques variées et précieuses, la propolis est actuellement utilisée en apithérapie et comme composant des cosmétiques et des « produits de santé ». L'article discute des plantes qui fournissent la propolis. Pour cela on utilise les données qui reposent sur des connaissances chimiques fiables et qui comportent des comparaisons entre échantillons de propolis et matériel végétal. La principale source de propolis dans la zone tempérée est l'exsudat des bourgeons de peuplier (Populus spp.) ; dans le Nord de la Russie, c'est l'exsudat de bouleau (Betula verrucosa). Quelques informations sont données concernant les sources de propolis en Australie (Xanthorrhoea spp.) et au Brésil (Araucaria spp., Baccharis spp.).

L'article fait le point sur les constituants nouveaux de la propolis publiés après 1994 et non inclus dans le dernier article de syn-

Table III. Compounds characteristic for propolis of different geographic origin.

\begin{tabular}{|c|c|c|}
\hline Geographical origin & Plant source & Typical constituents (main components) \\
\hline $\begin{array}{l}\text { Europe, Asia, } \\
\text { North America }\end{array}$ & Populus spp. (poplar) & $\begin{array}{l}\text { pinocembrin, pinobanksin, pinobanksin-3-O-acetate, } \\
\text { chrysin, galangin, caffeates (benzyl, phenylethyl, } \\
\text { prenyl) }[2,3,16,21,40,44,45]\end{array}$ \\
\hline Northern Russia & $\begin{array}{l}\text { Betula verrucosa } \\
\text { (birch) }\end{array}$ & $\begin{array}{l}\text { acacetin, apigenin, ermanin, rhamnocitrin, } \\
\text { kaempferid, } \alpha \text {-acetoxybetulenol }[43,44]\end{array}$ \\
\hline Brazil & $\begin{array}{l}\text { Baccahris spp. (?); } \\
\text { Araucaria spp. (?) }\end{array}$ & $\begin{array}{l}\text { prenylated } p \text {-coumaric acids }[1,9,14,47] \\
\text { prenylated acetophenones [9], diterpenic acids } \\
{[5,37,38]}\end{array}$ \\
\hline Canary Islands & unknown & furoruran lignans $[7,18]$ \\
\hline
\end{tabular}




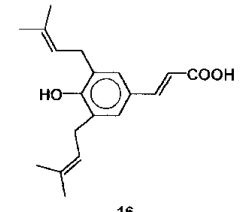

16

C-prenyl derivatives of p-coumaric acid

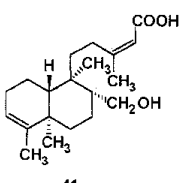

4

Diterpenic acids of clerodane type<smiles>CC1CCC2C(CO)=C3CCC(C)(C(=O)O)CCCC32CC1</smiles>

44

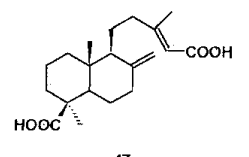

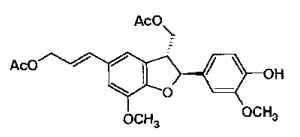

36

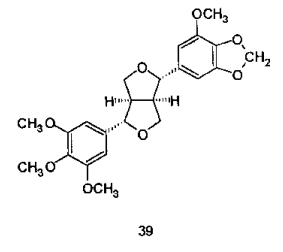

Ligans

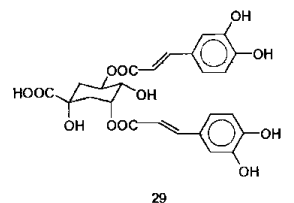

Dicaffeoylquinic acid

Diterpenic acids of labdane type

Figure 1. Chemical structures of selected new propolis constituents possessing valuable biological activities: 16 3,5-diprenyl-4-hydroxy-cinnamic acid; 18 2,2,-dimethyl-6-carboxyethenyl-2H-1-benzopyran; 41 ent-17-hydroxy-3,13Z-clerodadien-15-oic acid; 42 15-oxo-3,13Z-kolava-diene-17-oic acid; 44 imbricatoloic acid; 47 8(17),13E -labdadien-15,19-dioic acid; 35 3-acetoxymethyl-5-[(E)2-formylethen-1-yl]-2-(4-hydroxy-3-methoxyphenyl)-7-methoxy-2,3-dihydrobenzofuran; 39 sesartenin; 29 3,5-dicaffeoylquinic acid .

thèse de Marcucci [31] paru en 1995. Le tableau I donne la liste de ces nouveaux constituants et la figure 1 présente quelques structures chimiques. L'activité biologique des nouveaux constituants est indiquée dans le tableau II. Les récentes analyses concernant la composition de la propolis des abeilles sans aiguillon indigènes d'Amérique du Sud sont également passées en revue.

La composition chimique complexe et variable de la propolis crée un sérieux problème pour son utilisation médicale. Les principales difficultés sont liées à l'absence de tout contrôle concernant l'origine et de l'origine dépend la composition. La connaissance par l'analyse chimique de composés actifs pourrait conduire à la formulation d'un certain nombre de standards « locaux » basés sur l'origine botanique, comme par exemple un standard « européen », un standard « de Russie septentrionale » ou différents standards « brésiliens ». Le tableau III donne les constituants les plus typiques de la propolis de diverses origines géographiques et leur origine végétale.

Propolis / origine végétale / abeilles sans aiguillon / dérivé phénolé / terpène / Apis mellifera

Zusammenfassung - Propolis: neue Erkenntnisse über Chemie und pflanzlichen Ursprung. Propolis hat viele verschiedene Funktionen. Es wird von Bienen zum Bau und Erhalt ihrer Nester benutzt. Heutzutage wird es auf Grund seiner Viel- 
seitigkeit und wertvollen biologischen Aktivität in der Apitherapie, als Kosmetikzusatz und bei "Gesundheitskost" angewendet.

Dieser Beitrag diskutiert, von welchen Pflanzen dieser "Bienenkitt" stammt. Dabei werden Daten verwendet, die auf verlässlichen chemischen Erkenntnissen beruhen und die den Vergleich zwischen Propolisproben und Pflanzenmaterial beinhalten. In den gemässigten Zonen stammt der Kittharz vorwiegend von Knospenschuppen der Pappeln (Populus spp.) und in Nordrussland von Aussonderungen der Birkenknospen (Betula verucosa). Es gibt einige chemische Indikationen über Propolispflanzen in Australien (Xanthorroea spp.) und Brasilien (Auraucaria spp., Baccharis spp.).

Diese Arbeit gibt Informationen über neue Bestandteile im Propolis, die erst nach 1994 beschrieben wurden und nicht im letzten Übersichtsartikel von Marcucci 1995 [31] enthalten sind. Die neuen Bestandteile des Propolis sind in Tabelle 1 aufgelistet, die chemischen Strukturen von einigen sind in Abbildung 1 dargestellt. Die biologische Aktivität der neuen Verbindungen wird in Tabelle II angegeben. Die neuen Analysen über die chemische Zusammensetzung des Propolis der in Südamerika heimischen Stachellosen Bienen werden ebenfalls zusammengefasst.

Die komplexe und variable chemische Zusammensetzung von Propolis stellt ein sehr großes Problem bei seiner medizinischen Anwendung dar. Die hauptsächlichen Schwierigkeiten entstehen durch die fehlende Kontrolle über seinen Ursprung, und von diesem Ursprung hängt die Zusammensetzung ab. Unter Einbeziehung der chemischen Analysen könnte eine Reihe "lokaler" Standards, basierend auf der pflanzlichen Herkunft, formuliert werden, wie $\mathrm{z}$ B. ein "europäischer", "nordrussischer" und verschiedene brasilianische Standards usw. Tabelle III zeigt die typischsten Bestandteile des Propolis von verschiedenen geographischen Orten und ihre pflanzliche Herkunft.
Propolis / Pflanzenursprung / stachellose Bienen / Phenolderivate / Terpene / Apis mellifera

\section{REFERENCES}

[1] Aga H., Shibuya T., Sugimoto T., Kurimoto M., Nakajima Sh., Isolation and identification of antimicrobial compounds in Brazilian propolis, Biosci. Biotech. Biochem. 58 (1994) 945-946.

[2] Bankova V., Kuleva L., Phenolic compounds of propolis from different regions of Bulgaria, Animal Sci. 26 (1989) 94-98 (in Bulgarian).

[3] Bankova V., Dyulgerov A., Popov S., Evstatieva L., Kuleva L., Pureb O., Zamjansan Z., Propolis produced in Bulgaria and Mongolia: phenolic composition and plant origin, Apidologie 23 (1992) 79-85.

[4] Bankova V., Christov R., Kujumgiev A., Marcucci M.C., Popov S., Chemical composition and antibacterial activity of Brazilian propolis, Z. Naturforsch. 50c (1995) 167-172.

[5] Bankova V., Marcucci M.C., Simova S., Nikolova N., Kujumgiev A., Popov S., Antibacterial diterpenic acids from Brazilian propolis, Z. Naturforsch. 51c (1996) 277-280.

[6] Bankova V., Nikolova N., Marcucci M., A new lignan from Brazilian propolis, Z. Naturforsch. 51b (1996) 735-737.

[7] Bankova V., Christov R., Delgado Tejera A., Lignans and other constituents of propolis from the Canary Islands, Phytochemistry 49 (1998) 1411-1415.

[8] Bankova V., Christov R., Marcucci C., Popov S., Constituents of Brazilian geopropolis, Z. Naturforsch. 53c (1998) 402-406.

[9] Banskota A.H., Tezuka Y., Prasain J.K., Matsushige K., Saiki I., Kadota Sh., Chemical constituents of Brazilian propolis and their cytotoxic activities, J. Nat. Prod. 61 (1998) 896-900.

[10] Basnet P., Matsushige K., Hase K., Kadota S., Potent antihepatotoxic activity of dicaffeoyl quinic acids from propolis, Biol. Pharm. Bull. 19 (1996) 1479-1484.

[11] Basnet P., Matsuno T., Neidlein R., Potent free radical scavenging activity of Propolis isolated from Brazilian propolis, Z. Naturforsch. 52c (1997) 828-833.

[12] Bohlmann F., Kramp W., Grenz M., Robinson H., King R., Diterpenes from Baccharis species, Phytochem. 20 (1981) 1907-1913.

[13] Borcic I., Radonic A., Grzunov K., Comparisom of the volatile constituents of propolis gathered in different regions of Croatia, Flavour Fragrance J. 11 (1996) 311-313. 
[14] Boudourova-Krasteva G., Bankova V., Sforcin J.M., Nikolova N., Popov S., Phenolics from Brazilian propolis, Z. Naturforsch. 52c (1997) 676-679.

[15] Burdock G.A., Review of the biological properties and toxicity of bee propolis (propolis), Food Chem. Toxicol. 36 (1998) 347-363.

[16] Chi J., Xue B., Chen H., The chemical constituents of flavonoids from Liaoxi propolis, Zhangguo Yaoxue Zazhi 31 (1996) 264-266 (in Chinese).

[17] Christov R., Bankova V., Hegazi A., Abd El Hady F., Popov S., Chemical composition of Egyptian propolis, Z. Naturforsch. 53c (1998) 197-200.

[18] Christov R., Bankova V., Tsvetkova I., Kujumgiev A., Delgado Tejera A., Antibacterial furofuran lignans from Canary Island propolis, Fitoterapia 70 (1999) 89-92.

[19] Crane E., Beekeeping: Science, Practice and World Recourses, Heinemann, London, 1988.

[20] Diaz N.J., Quevedo Alvarez O., Saucedo B.L., Determination of $\mathrm{Fe}, \mathrm{Mn}, \mathrm{Zn}$ and $\mathrm{Cu}$ in an ethanolic extract of Cuban propolis, Rev. Cienc. Quim. 28 (1997) 93-95 (CA 128: 93303a).

[21] Garcia-Viguera C., Ferreres F., Tomas-Barberan F.A., Study of Canadian Propolis by GC-MS and HPLC, Z. Naturforsch. 48c (1993) 731-735.

[22] Ghisalberti E.L., Jefferies P.R., Lanteri R., Matisons J., Constituents of propolis, Experientia 34 (1978) 157-158.

[23] Ghisalberti E.L., Propolis: a review., Bee Wld 60 (1978) 59-84.

[24] Greenaway W., Scaysbrook T., Whatley F.R., The analysis of bud exudate of Populus $x$ euramericana, and of propolis, by gas chromatography-mass spectrometry, Proc. R. Soc. London B 232 (1987) 249-272.

[25] Kerr W., Abelhas indigenas brasileiras (meliponineos) na polinizcao e na producao de mel, polen, geopropolis e cera, Inf. Agropec. Belo Horizonte, 13 (1987) 15-27.

[26] Kivalkina V.P., Barskov A.A., Gubkina N.I., Talan V.A., Dubovenko J.V., Schmidt E.E., Propolis fractioning and the study of the microbicidal action of the fractions, Proc. XXV Int. Beekeeping Congr., Grenoble, 1975, Apimondia Publ. House, Bucharest, 1976, pp. 225-229.

[27] Koenig B., Plant sources of propolis, Bee World 66 (1985) 136-139.

[28] Kulevanova Sv., Stafilov T., Dorevski K., Determination of some macroelements in propolis by atomic absorption spectroscopy, Acta Pharm. (Zagreb) 45 (1995) 45-52.

[29] Lavie P., The relationship between propolis, poplar buds (Populus spp.) and castoreum, Proc. XXV Int. Beekeeping Congr., Grenoble, 1975, Apimondia Publ. House, Bucharest, 1976, pp. 229-233.
[30] Maciejevicz W., Scheller S., Danievski M., gas chromatography/mass spectrometry investigation of propolis, Analysis of sesquiterpenes, Acta Pol. Pharm. 40 (1983) 251-253.

[31] Marcucci M.C., Propolis: chemical composition, biological properties and therapeutical activity, Apidologie 26 (1995) 83-99.

[32] Marcucci M.C., Rodriguez J., Ferreres F., Bankova V., Groto R., Popov S., Chemical composition of Brazilian propolis from São Paulo state, Z. Naturforsch. 53c (1998) 117-119.

[33] Markham K.R., Mitchell K.A., Wilkins A.L., Daldy J.A., Lu Y., HPLC and GC-MS identification of the major organic constituents in New Zealand propolis, Phytochem. 42 (1996) 205-211.

[34] Martos I., Cossentini M., Ferreres F., TomasBarberan F.A., Flavonoid Composition of Tunisian honey and propolis, J. Agric. Food Chem. 54 (1997) 2824-2829.

[35] Matsuda Sh., Propolis-health care food, Foods \& Food Ingred. J. Jap. 160 (1994) 64-73.

[36] Matsuno T., Jung S.-K., Matsumoto Y., Saito M., Morilawa J., Preferential cytotoxicity to tumor cells of 3,5-diprenyl-4-hydroxycinnamic acid (artepillin C) isolated from propolis, Anticancer Res. 17 (1997) 3565-3568.

[37] Matsuno T., A new clerodane diterpenoid isolated from propolis, Z. Naturforsch. 50c (1995) 93-97.

[38] Matsuno T., Matsumoto Y., Saito M., Morikawa J., Isolation and characterization of cytotoxic diterpenoid isomers from propolis, Z. Naturforsch. 52c (1997) 702-704.

[39] Matsuno T., Saito M., Matsumoto Y., Morikawa J., A new benzo- $\gamma$-pyran derivative isolated from propolis, Z. Naturforsch. 53c (1998) 1037-1039.

[40] Nagy E., Papay V., Litkei G., Dinya Z., Investigation of the chemical constituents, particularly the flavonoid components, of propolis and Populi gemma by the GC/MS method, Stud. Org. Chem. (Amsterdam) 23 (1986) 223-232.

[41] Negri G., Marcucci M.C., Salatino A., Salatino M.L.F., Hydrocarbons and monoesters of propolis waxes from Brazil, Apidologie 29 (1998) 305-314.

[42] Pochinkova P., Bee Products in Medicine, Bulg. Acad. Sci. Publ. House, Sofia, 1986 [in Bulgarian].

[43] Popravko S.A., Chemical composition of propolis, its origin and standardization, in: A Remarkable Hive Product: PROPOLIS, Apimondia Publ. House, Bucharest, 1978, pp. 15-18.

[44] Popravko S.A., Sokolov M.V., Plant sources of propolis, Pchelovodstvo 2 (1980) 28-29 (in Russian).

[45] Tamas M., Marinescu I., Ionescu F., Flavonoidele din muguri de plop, Stud. Cercet. Biochim. 22 (1979) 207-213. 
[46] Tatefuji T., Izumi N., Ohta T., Arai Sh., Ikeda M., Kurimoto M., Isolation and identification of compounds from Brazilian propolis which enhance macrophage spreading and mobility, Biol. Pharm. Bull. 19 (1996) 966-970.

[47] Tazawa Sh., Warashina T., Noro T., Miyase T., Studies on the constituents of Brazilian propolis, Chem. Pharm. Bull. 46 (1998) 1477-1479.

[48] Tomas-Barberan F.A., Garcia-Viguera C., VitOlivier P., Ferreres F., Tomas-Lorente F., Phytochemical evidence for the botanical origin of tropical propolis from Venezuela, Phytochem. 34 (1993) 191-196.
[49] Valcic S., Montenegro G., Timmermann B., Lignans from Chilean propolis, J. Nat. Prod. 61 (1998) 771-775.

[50] Vanhaelen M., Vanhaelen-Fastre R., Propolis I. Origine, micrographie, composition chimique et activité thérapeutique, J. Pharm. Belg. 34 (1979) 253-259.

[51] Walker P., Crane E., Constituents of propolis, Apidologie 18 (1987) 327-334.

[52] Wollenweber E., Buchmann S.L., Feral honey bees in the Sonoran Desert: propolis sources other than poplar (Populus spp.), Z. Naturforsch. 52c (1997) 530-535. 
